\title{
Global survey on lime kiln operation, energy consumption, and alternative fuel usage
}

\author{
SABRINA FRANCEY, HONGHI TRAN, AND NIKLAS BERGLIN
}

\begin{abstract}
In late 2008, a survey on lime kiln operation and fuel usage was conducted through questionnaires distributed to pulp mills in nine countries. Responses were received from 59 pulp mills, totaling 67 lime kilns. This paper discusses the key findings from the survey with respect to kiln design parameters, operating data, control strategies, fuel types, energy consumption, and operating issues. Where possible, comparisons were made with findings obtained from a similar survey conducted in 1991. Over the past two decades many improvements have been made in kiln design and operation. Included are a larger number of kilns equipped with product coolers and lime mud dryers, along with changes designed to deliver higher mud dry solids content to the kiln. However, ring formation and dusting/high dust load remain the major operational issues among the respondents. Although few kilns have used alternative fuels to date, there is considerable industry interest in their use in the future. About twothirds of the kilns have plans for implementing alternative fuels within the next five years.
\end{abstract}

Application: This survey was designed and conducted with pulp mills in mind. Mill personnel may compare their operation with other mills around the world today so that they can gain insights on trends in lime kiln operations.

D ue to high energy costs and stringent environmental regulations in recent years, many kraft pulp mills have made it a priority to reduce their energy consumption. Many mills have done this by improving their lime kiln thermal efficiency and by displacing natural gas and fuel oil with alternative fuels. Strategies for lowering energy costs vary greatly from mill to mill due to the large differences in kiln design/operation and in alternative fuel cost, availability, heating value, composition, and combustion behavior.

A global survey was conducted to gather information on lime kiln operation and energy usage, and on the current status of alternative fuel use in kraft pulp mill lime kilns. Questionnaires were sent to mills in Argentina, Australia, Brazil, Canada, Chile, Finland, New Zealand, Norway, Sweden, and the United States. Responses were received from 59 pulp mills, totaling 67 lime kilns, from all of the previously mentioned countries except Chile. Each response represents one kiln. Figure 1 shows responses by region. The number of responses accounts for about $22 \%$ of the total lime kilns that are in operation in kraft pulp mills in the world today. This should provide a good snapshot of global lime kiln operations.

This paper discusses the key findings obtained from the survey, including lime kiln design parameters, operating data, control strategies, fuels, energy consumption, and operating issues. Where possible, comparisons are drawn between the current results and those from a survey conducted in the early 1990s on lime kiln operation and ringing problems [1].

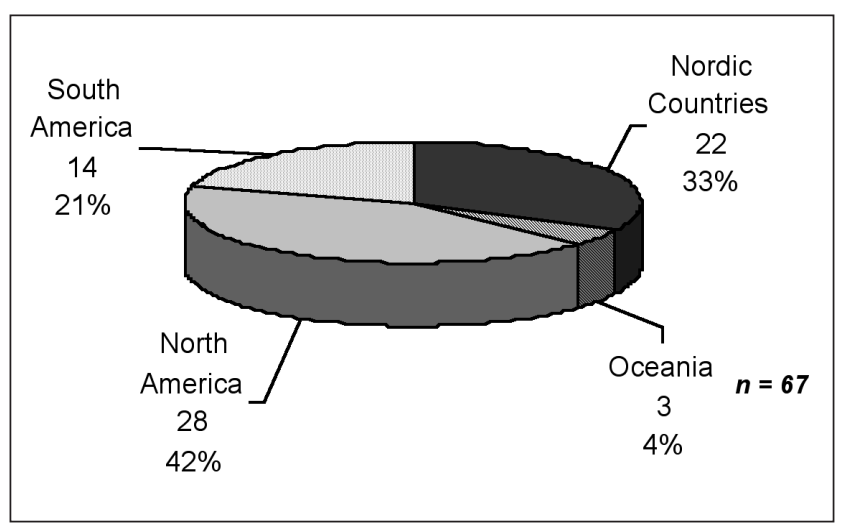

1. Responses by region (where Oceania includes New Zealand and Australia).

\section{DESIGN PARAMETERS}

Of the 67 kilns surveyed, 26 were built by Andritz/Ahlström; 17 by F.L. Smidth; 11 by Fuller/Traylor; five by Metso Minerals; two by Allis Chalmers and five by others. Only 50 respondents indicated the year of kiln startup. As Fig. 2 shows, the largest number of kilns was installed in the 1970s. Eight kilns have been built since 2000, five in Brazil and one each in Canada, Finland, and Sweden.

The average kiln dimensions are $3.5 \mathrm{~m}$ in diameter and $92 \mathrm{~m}$ in length. Lime kilns are larger now compared with the results from the 1991 survey, where the average dimensions were $3.2 \mathrm{~m}$ by $90 \mathrm{~m}$. The kiln capacity has increased substantially over the years (Fig. 3). The average kiln design capac- 


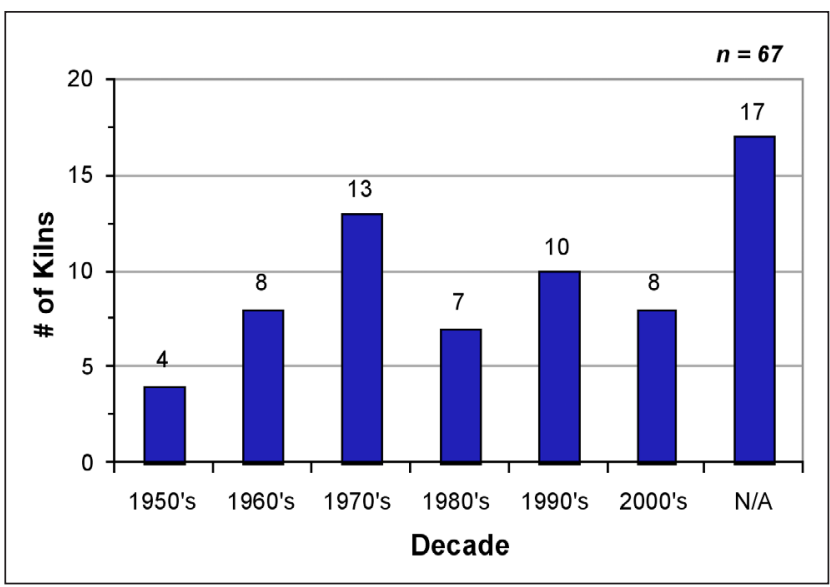

2. Kiln startup years, shown as distribution over the decades.

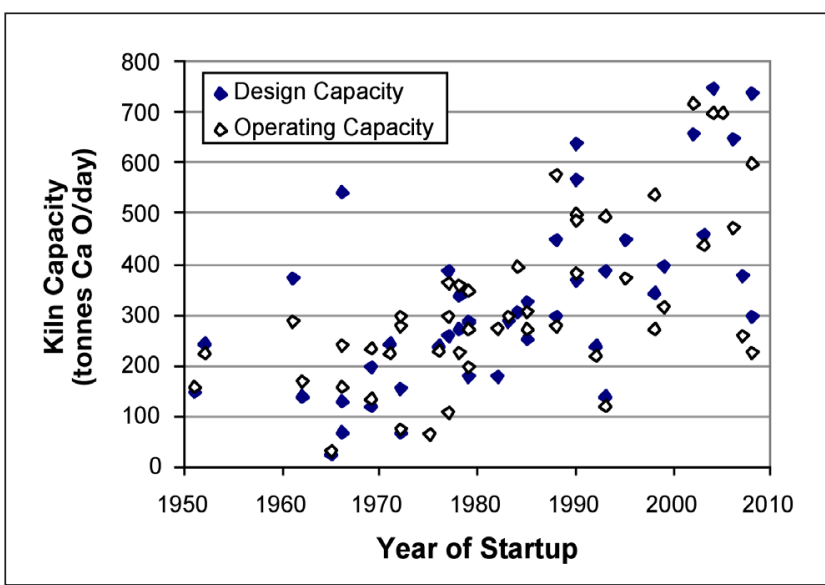

\section{Kiln operating capacity as a function of kiln startup year.}

ity is about 320 tonnes (metric tons)/day $\mathrm{CaO}$, ranging from 27 to 750 metric tons/day $\mathrm{CaO}$, which is significantly larger than that in the 1991 survey, where the average design capacity was 190 metric tons/day CaO. Large, modern kilns may have a volume up to $2500 \mathrm{~m}^{3}$ (Fig.4).

Nearly $80 \%$ of the kilns are fitted with product coolers, a substantial increase over the results from the 1991 survey, where only 53\% were so equipped. As Fig. 5 indicates, most kilns built in the 1990s and all since 2000 are equipped with product coolers. Forty kilns use chains only to dry lime mud, 22 are equipped with lime mud dryers (LMD), and five use both chains and LMD. Of the 45 kilns that use chains, 10 use Garland chains, three low density curtain chains, six high density curtain chains, six diamond shape (Jammbco) chains, and four use "Other". The remaining 16 utilize a combination of two or three chain types.

Figure 6 shows the types of refractory bricks used at the front end of the kilns. Half of the respondents use double brick and almost one-third use single brick, while three respondents indicated that they use a combination of single and double brick. Eight respondents selected "Other" for brick type, such as blue ram, castable, monolithic, and refractory concrete. Compared to the 1991 survey results, the proportion of

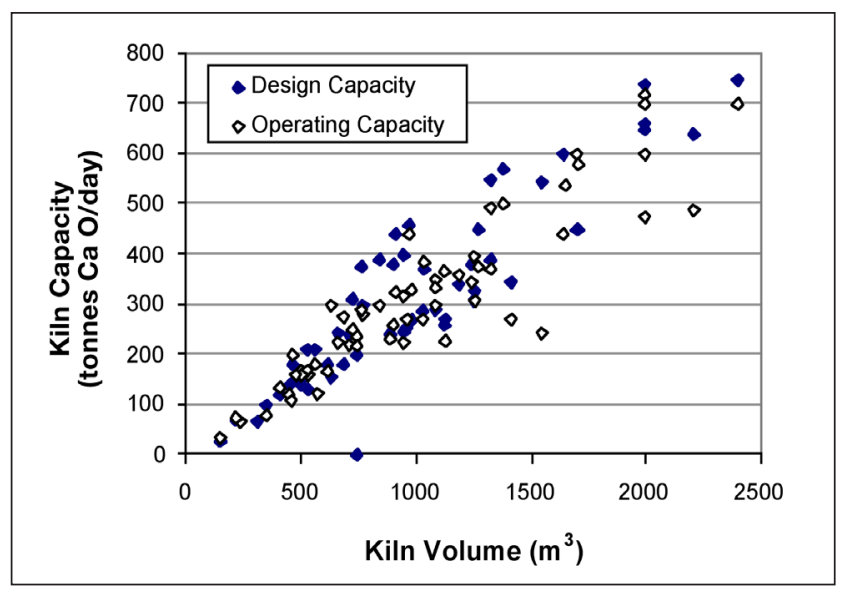

4. Kiln capacity as a function of kiln volume.

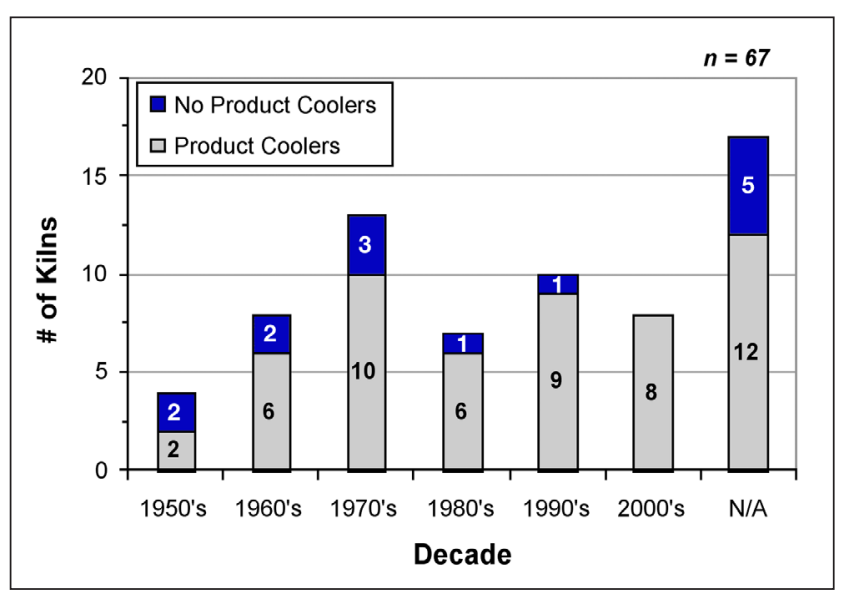

\section{Lime kiln startup distribution, product coolers indicated.}

kilns using double brick has decreased from two-thirds to about half, although the proportion of kilns using single brick has remained about the same.

\section{OPERATING DATA AND KILN CONTROL \\ Operating data}

Figure 4 shows the operating rates for the kilns, along with the design capacities. Forty-seven kilns in this survey operate within $\pm 25 \%$ of their design capacity. Of those operating outside this design capacity range, one operates at below $50 \%$, while two operate at over $150 \%$ of their rated capacity.

The average temperature at various points in the kiln, along with the range of answers given by respondents, is

\begin{tabular}{|l|c|c|}
\hline Temperature $\left({ }^{\circ} \mathrm{C}\right)$ & Average & Range \\
\hline Feed end gas temperature & 365 & $150-1000$ \\
\hline Front end gas temperature & 940 & $300-1600$ \\
\hline $\begin{array}{l}\text { Product temperature } \\
\text { before coolers }\end{array}$ & 960 & $400-1200$ \\
\hline $\begin{array}{l}\text { Product temperature } \\
\text { after coolers }\end{array}$ & 280 & $100-900$ \\
\hline
\end{tabular}

\section{Gas and product temperatures.}




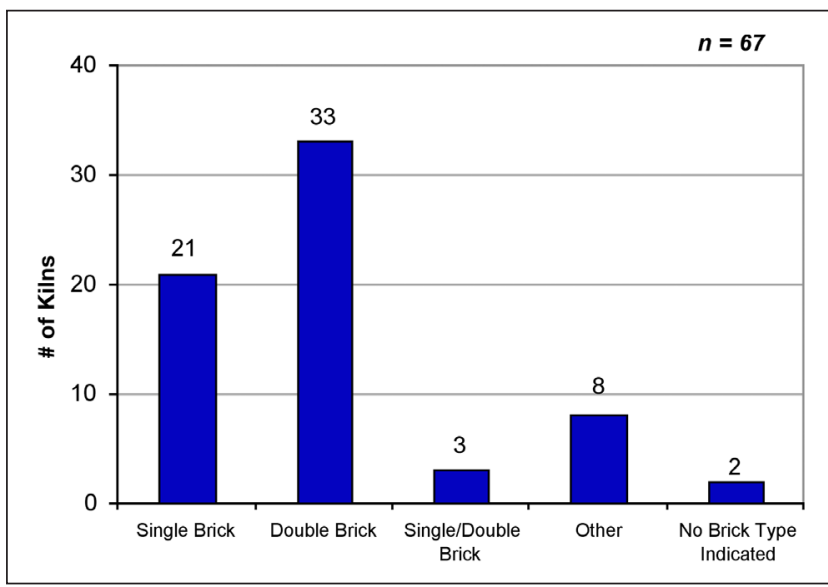

6. Front end refractory brick type.

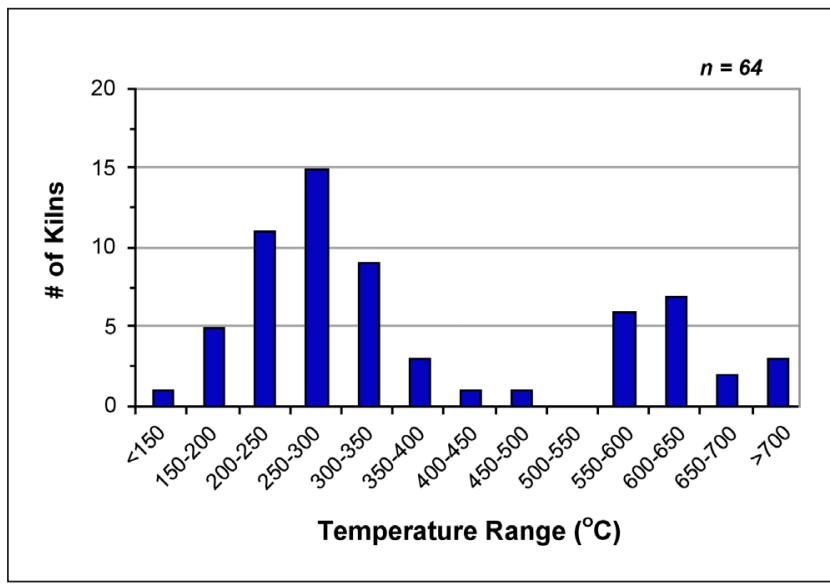

\section{Feed end gas temperature distribution.}

\begin{tabular}{|c|c|c|}
\hline Parameter & Average & Range \\
\hline Mud solids (wt\%) & 75 & $37-89$ \\
\hline Mud soda content (wt $\left.\% \mathrm{Na}_{2} \mathrm{O}\right)$ & 0.4 & $0.0-2.5$ \\
\hline Residual $\mathrm{CaCO}_{3}(\mathrm{wt} \%)$ & 2.9 & $1-12$ \\
\hline Lime availability (wt\%) & 87 & $34-99$ \\
\hline Sulfidity (\% on AA) & 33 & $22-42$ \\
\hline $\mathrm{AA}\left(\mathrm{g} / \mathrm{L} \mathrm{Na} \mathrm{N}_{2} \mathrm{O}\right)$ & 105 & $93-124$ \\
\hline TTA $\left(\mathrm{g} / \mathrm{L} \mathrm{Na}{ }_{2} \mathrm{O}\right)$ & 125 & $108-155$ \\
\hline CE (\%) & 80 & $73-88$ \\
\hline
\end{tabular}

II. Selected mud, lime, and liquor properties (AA = active alkali; TTA = total titratable alkali; $C E$ = causticizing efficiency).

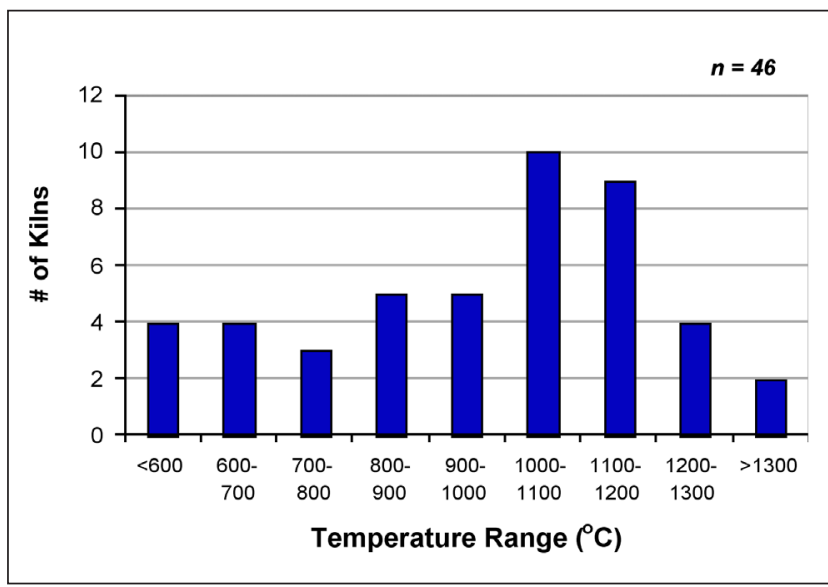

\section{Front end gas temperature distribution}

shown in Table 1 . The average feed end temperature is $365^{\circ} \mathrm{C}$, which is considerably higher than that in the 1991 survey $\left(220^{\circ} \mathrm{C}\right)$. This is expected, as more kilns are fitted with $\mathrm{LMD}$, which require a higher gas temperature to operate.

Figure 7 shows the distribution of kiln feed end gas temperatures, which appears to be bimodal. The kilns with temperatures centered in the $250-300^{\circ} \mathrm{C}$ range do not have $\mathrm{LMD}$, while those centered in the $600-650^{\circ} \mathrm{C}$ range are equipped with LMD.

Figure 8 shows the distribution of front end gas temperatures. The responses varied widely, from as low as $270^{\circ} \mathrm{C}$ to as high as $1600^{\circ} \mathrm{C}$. This wide variation is not surprising due to the inherent difficulties in accurately measuring gas temperatures at the front end of the kiln. The most common temperature range, however, is $1000-1100^{\circ} \mathrm{C}$.

Table 2 summarizes selected mud, lime, and liquor property data. The average dry solids content of lime mud to kiln is $75 \mathrm{wt} \%$, with responses varying from 37 to $89 \mathrm{wt} \%$. This average is about $5 \mathrm{wt} \%$ higher than that reported in the 1991 survey. The average soda content of lime mud to kiln is 0.4 wt $\% \mathrm{Na}_{2} \mathrm{O}$, slightly lower than the $0.5 \mathrm{wt} \% \mathrm{Na}_{2} \mathrm{O}$ level reported in the 1991 survey.

The quality of product lime was represented by residual $\mathrm{CaCO}_{3}$ content and lime availability. The overall average residual $\mathrm{CaCO}_{3}$ is $2.9 \mathrm{wt} \%$, ranging from 1 to $11.9 \mathrm{wt} \%$, although the majority of responses are between 1.5 and $3.5 \mathrm{wt} \%$. The overall average availability is about $87 \mathrm{wt} \% \mathrm{CaO}$. Aside from one outlier, responses range from 80 to $99 \mathrm{wt} \% \mathrm{CaO}$, although the majority

\begin{tabular}{|l|c|c|c|c|c|c|c|c|}
\hline \multirow{2}{*}{ Region } & \multicolumn{2}{|c|}{$\begin{array}{c}\text { TTA } \\
\left(\mathbf{g} / \mathrm{Na}_{\mathbf{2}} \mathbf{O}\right)\end{array}$} & \multicolumn{2}{c|}{$\begin{array}{c}\text { AA } \\
\left(\mathbf{g} / \mathrm{La}_{\mathbf{2}} \mathbf{O}\right)\end{array}$} & \multicolumn{2}{c|}{$\begin{array}{c}\text { Sulfidity } \\
(\% \text { on AA) }\end{array}$} & \multicolumn{2}{c|}{$\begin{array}{c}\text { CE } \\
(\%)\end{array}$} \\
\hline & Avg. & Range & Avg. & Range & Avg. & Range & Avg. & Range \\
\hline North America $(\mathrm{n}=25)$ & 120 & $110-128$ & 103 & $94-111$ & 31 & $23-38$ & 80 & $73-85$ \\
\hline South America $(n=3)$ & 122 & $108-136$ & 104 & $93-115$ & 33 & $22-40$ & 81 & $76-88$ \\
\hline Nordic countries $(n=21)$ & 132 & $120-155$ & 111 & $95-124$ & 38 & $32-42$ & 80 & $74-82$ \\
\hline Oceania $(n=3)$ & 122 & $119-128$ & 106 & $105-110$ & 36 & $34-40$ & 81 & $79-82$ \\
\hline
\end{tabular}

III. Regional variations in white liquor properties (AA = active alkali; $T T A=$ total titratable alkali; $C E=$ causticizing efficiency). 
of the figures are between 83 and $92 \mathrm{wt} \% \mathrm{CaO}$. The average causticizing efficiency is $80 \%$, ranging from 73 to $88 \%$.

The average and range of typical responses for white liquor sulfidity (on active alkali [AA]) are shown for various regions in Table 3. The highest regional average is in the Nordic countries at $38 \%$ on AA, followed by Oceania (Australia and New Zealand) at $36 \%$ on AA, South America at $31 \%$ on AA and North America at $30 \%$ on AA. A similar trend was also evident in the 1991 survey, where the Nordic mills were running at an average of $34 \%$ on AA and the North American mills were running at a lower sulfidity of $29 \%$ on AA.

The Nordic mills have a much higher AA than the mills in the Americas, $111 \mathrm{~g} / \mathrm{L} \mathrm{Na}_{2} \mathrm{O}$ compared to $103 \mathrm{~g} / \mathrm{L} \mathrm{Na}_{2} \mathrm{O}$. The $\mathrm{AA}$ at the mills in Oceania falls between these two groups, at $106 \mathrm{~g} / \mathrm{L} \mathrm{Na}_{2} \mathrm{O}$. A similar trend was again evident in the 1991 survey, where the Nordic mills had a higher AA than the North American mills (121 g/L Na $\mathrm{Oa}_{2} \mathrm{O}$ versus $100 \mathrm{~g} / \mathrm{L} \mathrm{Na}_{2} \mathrm{O}$ ), although the regional difference in $\mathrm{AA}$ was larger.

\section{Kiln control strategies}

In this survey, each respondent was able to choose one or more control strategies. Thirty-one respondents indicated that they incorporate a kiln control package into their distributed control system (DCS). As Fig. 9 shows, the most common control strategy is to keep the residual carbonate within a specified range (33 respondents), followed by keeping feed end and front end temperatures constant (24 each), and "Other". Sixteen respondents selected the "Other" option, which includes staying below a maximum fuel consumption level and maintaining excess $\mathrm{O}_{2}$ at a specified level in order to be in compliance with TRS emission limits. Four respondents indicated that they do not have a kiln control strategy.

\section{KILN FUELS}

Figure 10 shows a breakdown of kiln fuel sources. The majority of kilns burn some form of fossil fuel (natural gas, fuel

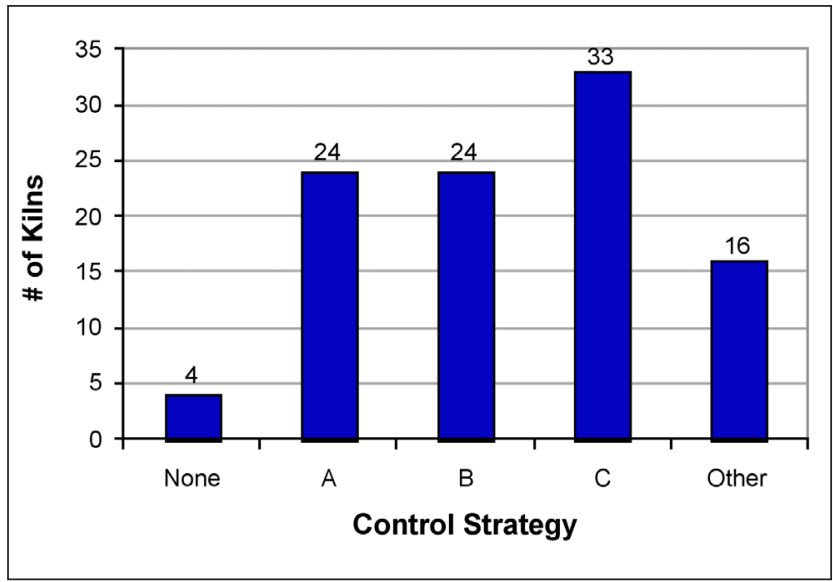

9. Kiln control strategies (note: respondents were allowed to select more than one option). $A=$ keep feed end temperature constant; $B=$ keep front end temperature constant; and $C=$ keep residual carbonate within a specified range.

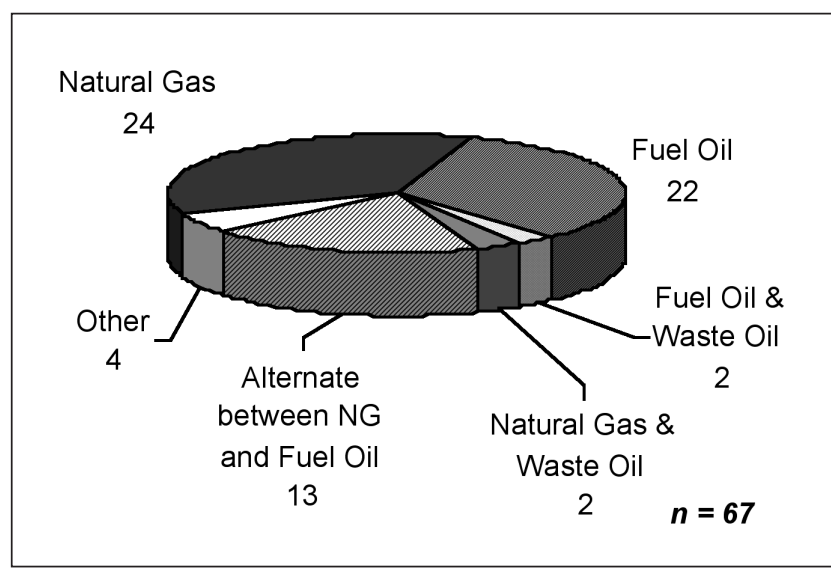

10. Main fuel burned in lime kilns. The four kilns in "Other" do not burn fossil fuels at all: three use tall oil pitch and one uses tall oil pitch and hydrogen.

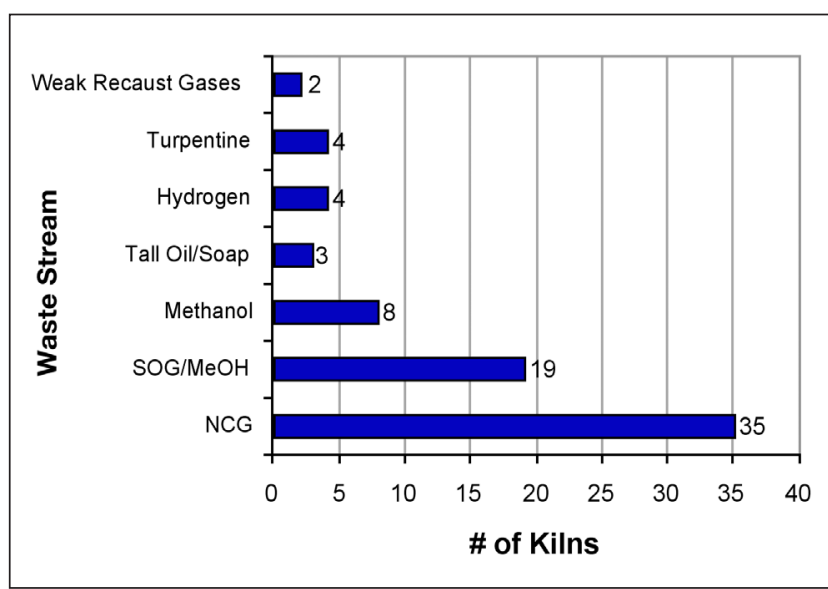

\section{Waste streams presently burned in lime kilns.}

oil, waste oil) as their main fuel. Four kilns do not burn fossil fuels at all. Three of these kilns use tall oil pitch and one uses tall oil pitch and hydrogen (a by-product from an adjacent chemical plant).

Figure 11 shows the variety of waste streams that are burned in the lime kilns. This includes kilns that burn waste streams constantly and kilns that burn waste streams occasionally. For the purpose of this analysis, the distinction between waste streams and alternative fuels is that waste streams are "wastes" from the mill or a nearby industry that the producer is obligated to incinerate or dispose of in an environmentally responsible manner and require little or no processing prior to being combusted in the kiln. Alternative fuels are those that are purchased from an outside vendor or are produced on site and require processing (e.g., drying, grinding, etc.) prior to being burned in the lime kiln.

\section{ALTERNATIVE FUEL USE}

Figure 12 summarizes the current status of alternative fuel use. Note that there are a number of mills that did not respond to the survey but are known to have used alternative fuels. The conclusions drawn from this survey are therefore only 


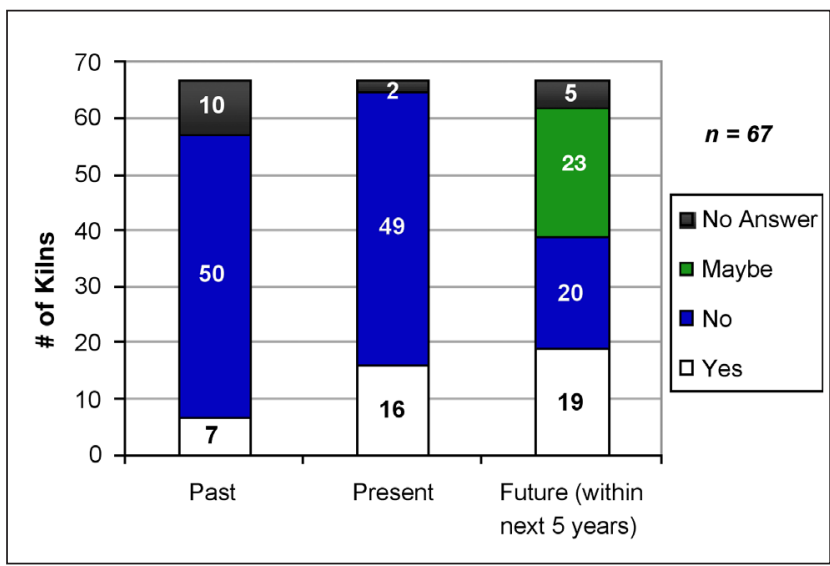

12. Past, present, and future use of alternative fuels in lime kilns.

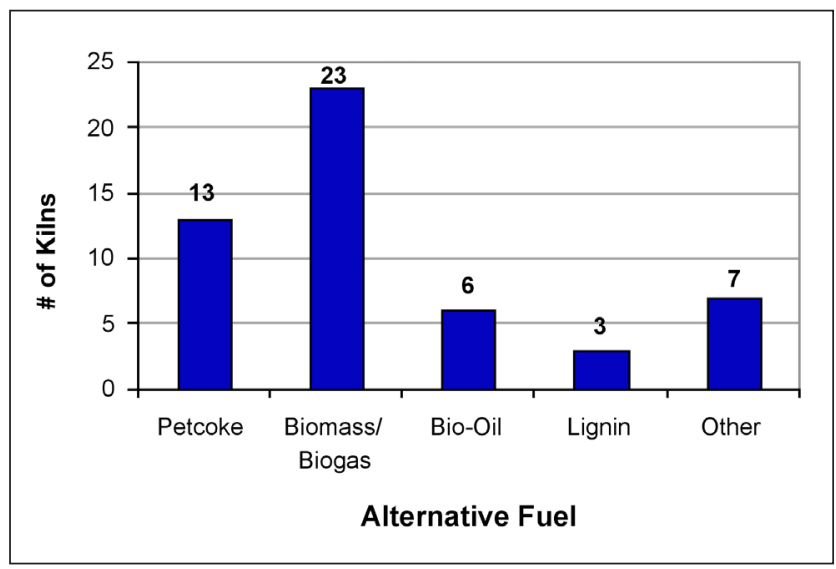

13. Alternative fuels being considered for future use. Note: "Other" options included alternative fuels olein and tall oil pitch, and waste streams tall oil, hydrogen, methanol, and turpentine.

representative of the sample of responses collected, as opposed to all lime kilns in operation today. The results show that the majority of respondents have never burned alternative fuels. Only 16 kilns presently burn alternative fuels: eight burn petcoke, six burn tall oil pitch, one burns olein biofuel (a fuel derived from animal fat), and one burns biogas and tall oil pitch. All the kilns that have used alternative fuels in the past or present are located in Brazil, Sweden, Finland, and the United States.

There is no clear relationship between kiln age and whether alternative fuels are being used in the kiln, mainly because almost half of the alternative fuel users did not specify the year of startup for their kiln. Two of the petcoke users reported an improvement in performance, four reported no change in performance, one reported worsened performance, and one petcoke user did not provide an answer to this question. The biogas user indicated that performance has stayed the same. One tall oil pitch user reported an improvement in performance, three reported no change, and another three did not provide an answer. The olein user indicated no change in its kiln performance.

It is also evident from Fig. 12 that many kilns appear to be

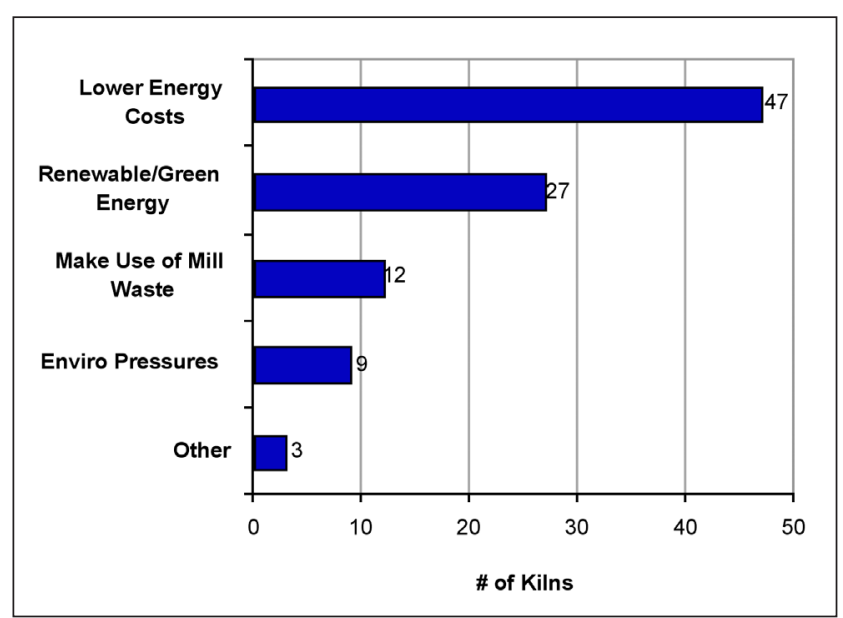

14. Main motivation for alternative fuel use. Note: "Other" options included avoiding fossil fuel $\mathrm{CO}_{2}$ emissions, better kiln operation, and in one case, the biodiesel plant located next to the kiln (source of biogas).

interested in using alternative fuels in the future: 19 kilns have definite plans and another 23 kilns might burn alternative fuels in the next 5 years. Figure 13 shows the most popular fuel being considered for future use is biomass/biogas, followed by petcoke, bio-oil, and precipitated lignin. Each respondent was allowed to select one or more alternative fuels.

Figure 14 shows that the most common motivation for alternative fuel use is by far lower energy costs, followed by renewable/green energy. Each kiln was allowed to select one or more motivations, and the results from this question are particularly interesting because they offer insight into the attitudes in industry towards alternative fuels.

\section{ENERGY CONSUMPTION}

In an era of fluctuating energy prices and with the advent of carbon taxes and cap and trade systems, lime kiln energy consumption has become a very important aspect of kiln operations and has begun to have a more prominent impact on overall mill profitability.

In this survey, the lime kiln heat rate (GJ of energy per metric ton of $\mathrm{CaO}$ production) was calculated for each kiln based on fuel consumption and lime production data. This was used as a measure of lime kiln energy efficiency. Figure 15 shows the distribution of heat rates. Based on the data provided for fuel consumption and kiln operating capacity received from the survey, it was possible to calculate the heat rate for only 48 of the respondents. Of these 48 kilns, over $80 \%$ have a heat rate between 5 and $8 \mathrm{GJ} /$ metric ton $\mathrm{CaO}$, with the most common range being between 6 and $7 \mathrm{GJ} /$ metric ton $\mathrm{CaO}$. Two of the kilns have heat rates below $5 \mathrm{GJ} /$ metric ton $\mathrm{CaO}$ and ten kilns have heat rates between 5 and $6 \mathrm{GJ} /$ metric ton $\mathrm{CaO}$. These heat rates are rather low and may not be realistic, especially those below $5 \mathrm{GJ} /$ metric ton $\mathrm{CaO}$.

Lime kiln heat rate is influenced by many factors, including fuel type, refractory type, the mud drying system (chain or 


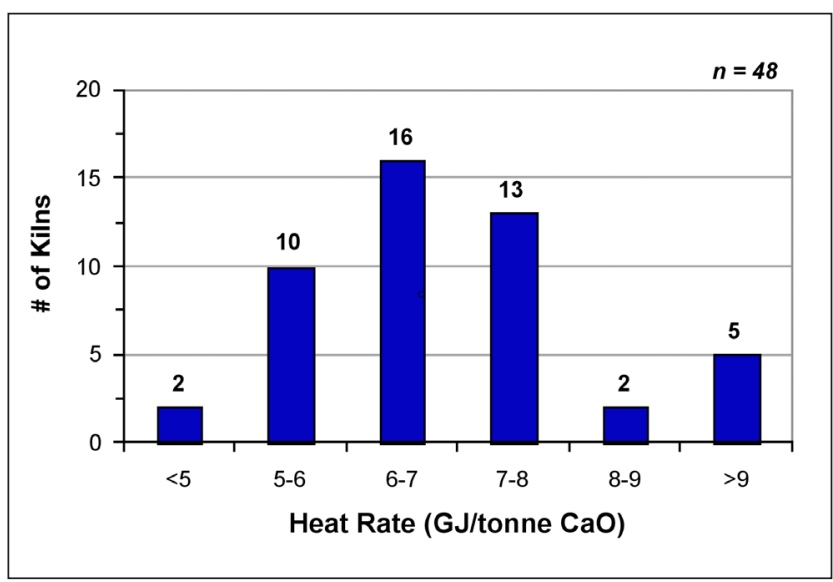

15. Kiln heat rate distribution.

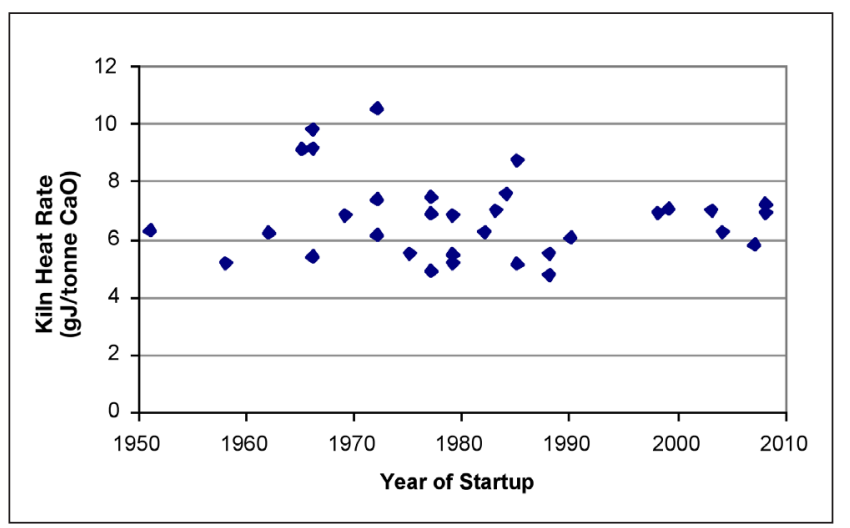

16. Kiln heat rate vs. startup year.

LMD), and whether or not the kiln is equipped with product coolers. To a lesser extent, the heat rate can also be influenced by amounts of excess air, dust losses, and inerts in lime [2]. In this analysis, the relationships between kiln heat rate and a variety of parameters gathered from the survey were explored. First, heat rate was plotted against the year of kiln startup in Fig. 16, since many advances in energy efficient design have been made over the years. The results show no clear trend, which is perhaps because many older kilns have since been retrofitted to improve energy efficiency (e.g., installed product coolers, improvements in refractory and chain systems, etc.).

The average heat rate for kilns with double bricks at the front end is $6.6 \mathrm{GJ} / \mathrm{metric}$ ton $\mathrm{CaO}$, understandably lower than the $7.4 \mathrm{GJ} /$ metric ton $\mathrm{CaO}$ rate for those with single bricks. Kilns with LMDs have a slightly lower heat rate than those with chains ( 6.6 versus $7.1 \mathrm{GJ} /$ metric ton $\mathrm{CaO}$ ), which is contrary to common observations that kilns with LMDs tend to have higher energy usage.

The average heat rate for 38 kilns with product coolers is $6.86 \mathrm{GJ} /$ metric ton $\mathrm{CaO}$, ranging from 4.83 to $10.6 \mathrm{GJ} / \mathrm{metric}$ ton $\mathrm{CaO}$. The average value for eight kilns without product coolers is essentially the same, $6.94 \mathrm{GJ} /$ metric ton $\mathrm{CaO}$, ranging from 5.18 to $9.18 \mathrm{GJ} /$ metric ton $\mathrm{CaO}$. This average value is unreasonably low since kilns without product coolers typically consume $25 \%$ more fuel than those with product coolers. With that being the case, they should have an average heat rate of about $8.7 \mathrm{GJ} /$ metric ton $\mathrm{CaO}$. One possible source of error in the calculation of heat rate is likely to be the mismatch of the data received.

\section{OPERATIONAL ISSUES}

In order to provide an insight into issues that are perceived to be the most important in lime kiln operation today, respondents were asked to rate their kiln operational issues on a scale of 0 to 4 , where:

$$
\begin{aligned}
0= & \text { Don't know } \\
1= & \text { Never occurred, excellent } \\
2= & \text { Occurred occasionally but posed no major } \\
& \text { problem (controllable, in compliance) } \\
3= & \text { Occurred often, a nuisance, needs attention } \\
4= & \text { Occurred often, very severe, intolerable, } \\
& \text { caused frequent kiln downtimes }
\end{aligned}
$$

Figure 17 shows a summary of operational issue scores provided by all mill respondents. It is important to note that in this figure, the " 0 " category includes both respondents who actually entered 0 and those who left the question blank. Figure 18 shows operating issues that occur often (i.e., received scores of 3 or 4 ).

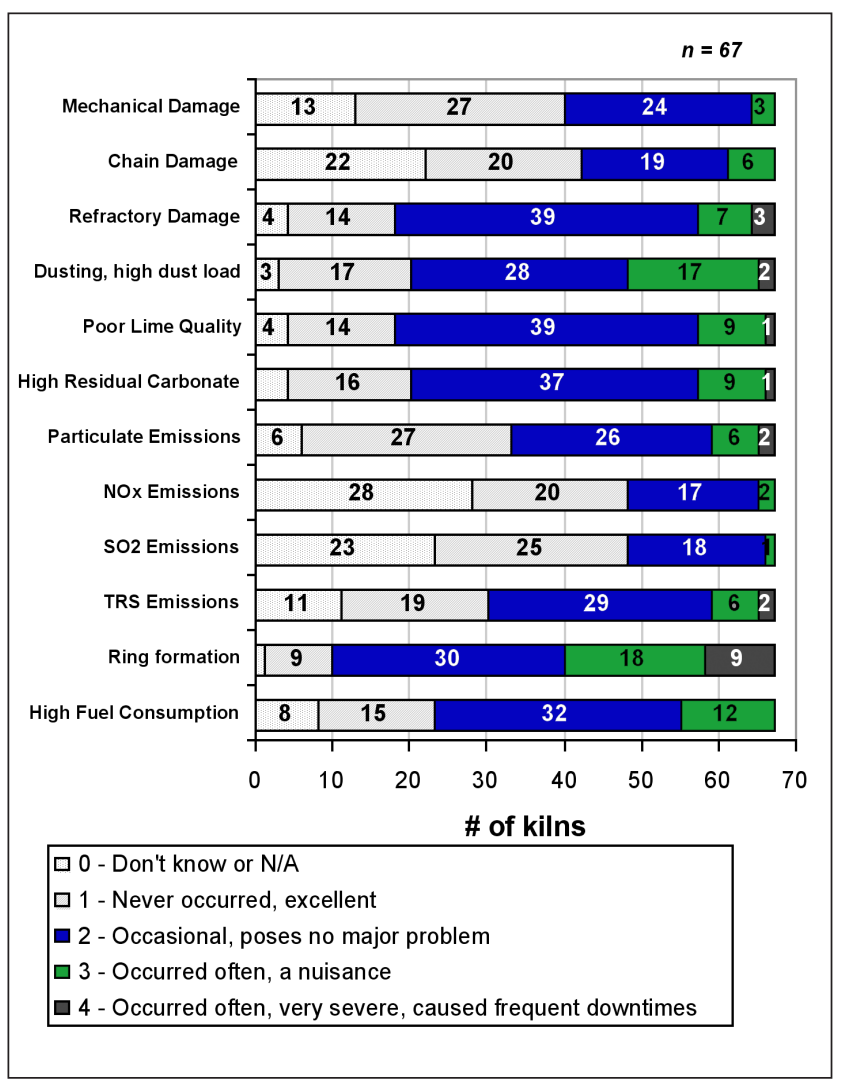

17. Perceived severity of various kiln operational issues 


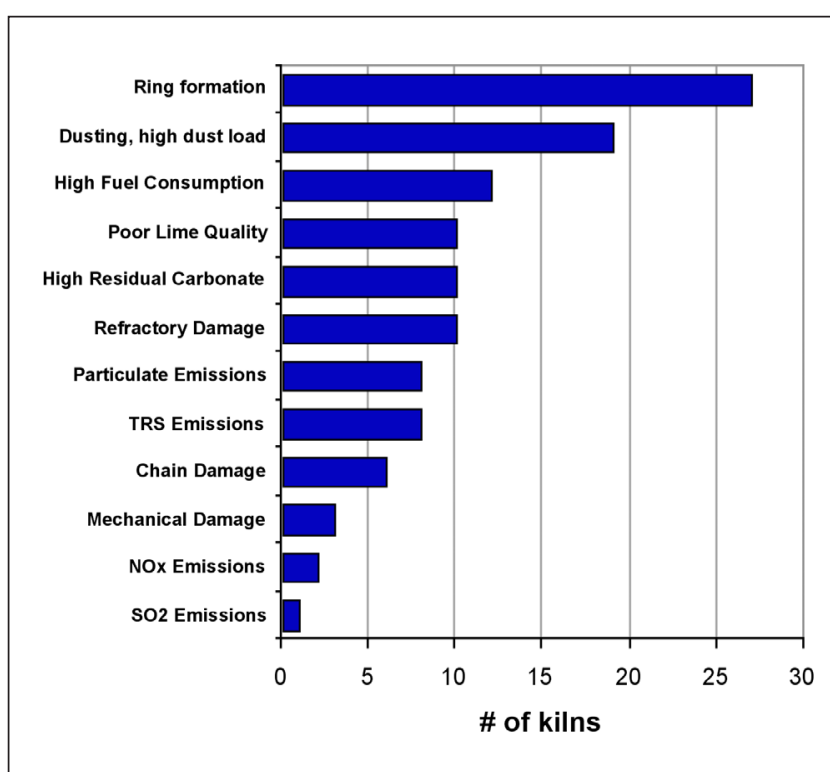

18. Operational issues that occur often (i.e., number of kilns with scores of 3 or 4 for each issue).

Out of the 12 operating issues listed, only seven of them received scores of 4 (occurred often, very severe). Ring formation had the most $4 \mathrm{~s}$ by far, indicating that it continues to be a severe problem in lime kiln operation. The other issues causing severe problems for respondents are refractory damage, dusting/high dust load, particulate emissions, TRS emissions, poor lime quality, and high residual carbonate.

Twenty-seven respondents reported that ringing occurs often (i.e., scores of 3 or higher), making ring formation the most frequently occurring major operational issue in this survey. From the data collected, there does not appear to be a correlation between fuel type and the frequency/severity of ring formation. This is because a variety of fuels are used among the nine respondents that gave a score of 4 to ring formation (three use natural gas, two use natural gas and petcoke, one alternates between waste oil and fuel oil, one uses pitch oil, and another uses a mixture of fuel oil, tall oil pitch, and biogas).

The incineration of NCG in lime kilns may have an effect on ringing because it makes the burner flame unstable, causing erratic temperature fluctuations at the front end. This in turn promotes ring hardening through recarbonation. The sulphur in NCG can also contribute to ring hardening through sulfation reactions at the front end of the kiln [5]. Interestingly, of the 18 kilns that burn NCG on a regular basis, 11 of them have a ring formation score greater than the average ring formation score from all respondents.

The second most frequently occurring operational problem according to the survey is dusting and high dust load, with a score of 3 or higher for 19 out of 67 responses. For poor lime quality and high residual carbonate, it is apparent from Figs. 17 and 18 that there are similar numbers of kilns in each category. The similarities are not surprising because lime quality and residual carbonate are directly linked, with residual carbonate being one of the major indicators of lime quality.

In terms of emissions, 66 out of 67 kilns gave a score of 2 or less for $\mathrm{SO}_{2}$ emissions, suggesting that $\mathrm{SO}_{2}$ emissions in general are not a problem. Similar results were found for $\mathrm{NO}_{\mathrm{x}}$ emissions, with 65 out of 67 kilns giving a score of 2 or less. Interestingly, of the respondents who gave scores of 2 or 3 , there was a disproportionately large number of respondents from the Nordic countries and a correspondingly small number from North America. Overall, North American mills were the source of a larger share of survey responses (42\%) than the Nordic mills (33\%). However, 56\% of the respondents who gave scores of 2 or 3 for $\mathrm{NO}_{\mathrm{x}}$ emissions were from Nordic countries, while only $22 \%$ of the respondents from this category were from North America. This trend reflects the fact that regulations on $\mathrm{NO}_{\mathrm{x}}$ emissions are more stringent in Nordic countries than in many North American jurisdictions.

\section{SUMMARY}

A global survey on lime kiln operation, energy consumption, and alternative fuel use was conducted, with responses from 59 pulp mills, totaling 67 lime kilns in Argentina, Australia, Brazil, Canada, Finland, New Zealand, Norway, Sweden, and the United States. Based on comparisons with results from the 1991 survey, over the past two decades many improvements have been made to kiln operations, including increases in the proportion of kilns equipped with product coolers and LMDs. The operational issue score results show that ring formation and dusting/high dust load were the most frequently occurring major operational issues among the respondents.

No clear relationships were evident between alternative fuel use and heat rate or operational issue scores. Although few kilns have used alternative fuels, it is evident that there is significant industry interest in their use in the future. Almost two-thirds of the kilns have definite or possible plans for implementing alternative fuels within the next five years. In this era of economic hardship and increasing political and regulatory attention towards reducing fossil fuel $\mathrm{CO}_{2}$ emissions, it is not surprising that the most common motivators for alternative fuel use are lower energy costs and renewable/ green energy.

It is important to note that this survey was distributed in late 2008 at a time when fuel oil and natural gas prices were high. The responses regarding alternative fuel use in particular reflect those times and may not be an accurate representation of the current level of use and interest in alternative fuels for lime kilns going forward. TJ

\section{ACKNOWLEDGEMENTS}

This work was part of the research program on "Alternative Fuels for Lime Kilns," jointly supported by the Natural Sciences and Engineering Research Council of Canada (NSERC), industrial members of the research consortium on "Increasing Energy and Chemical Recovery Efficiency in the Kraft Process," and the following companies: Alberta Pacific, Alberta 


\section{LIME KILN}

Research Council/Alberta Forestry Research Institute, DTE Petcoke, FPInnovations, Jammbco, Kiln Flame Systems, and Zellstoff Celgar. The authors greatly appreciate the effort and time spent by the individual respondents to complete the questionnaire, and would like to thank Mr. Alfredo Mokfienski of ABTCP, Brazil, and other individuals who assisted in distributing the questionnaire.

\section{LITERATURE CITED}

1. Notidis, E. and Tran, H., Tappi J. 76(5): 125(1993).

2. Adams, T.N., "Lime Kiln Principles and Operations," TAPPI Kraft Recovery Operations Seminar Notes, TAPPI PRESS, Atlanta, GA, USA, Session 2.2, p. 5.

3. Adams, T.N., "Alternative Fuel Impact on Lime Reburning Kiln Performance," TAPPI Eng., Pulping Environ. Conf., TAPPI PRESS, Atlanta, 2008 , p. 2550

4. Francey, S., "Impacts of Burning Alternative Fuels in Lime Kilns at Kraft Pulp Mills", Master's Thesis, University of Toronto, Toronto, ON, Canada, 2009

5. Tran, H.N., "Lime Kiln Chemistry and Effects on Kiln Operations," TAPPI Kraft Recovery Operations Seminar Notes, TAPPI PRESS, Atlanta, Session 2.3, p. 6.

\section{ABOUT THE AUTHORS}

We chose to research this topic to gain a better understanding of how lime kilns are currently operated globally. This work was part of the research program on "Alternative fuels for lime kilns" undertaken by our group. The paper is a follow up to an earlier paper, "Current status of alternative fuel use in lime kilns," from the October 2009 issue of TAPPI Journal, which discussed the process and operational impacts from using various alternative fuels in lime kilns.

The most difficult aspect of this research was coordinating and processing the responses we received, while ensuring that they were interpreted in a consistent and accurate manner. We were lucky to have an enthusiastic and conscientious group of respondents, and we were able to contact them when clarifications were required.

The most interesting part of the survey responses was the section that allowed respondents to comment on their attitudes towards and motivations for using alternative fuels in lime kilns. From a research standpoint, it is always interesting to gain insight into the perspectives of those who work at the mills on a dayto-day basis.

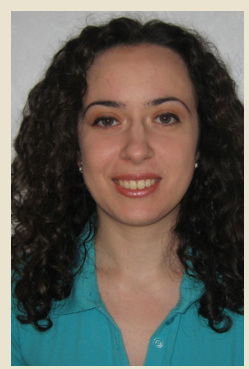

Francey

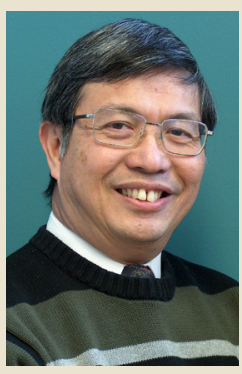

Tran

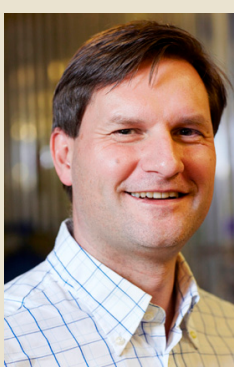

Berglin
This survey was designed and conducted with pulp mills in mind. The goal was to collect information on lime kiln operation, energy consumption, and alternative fuel use, so that mill personnel can see how their mill compares with others in operation around the world today, as well as gain insights on trends in lime kiln operations.

Francey is a graduate student and Tran is a professor with the Pulp \& Paper Centre, University of Toronto, Toronto, ON, Canada. Berglin is technical manager with Innventia AB in Stockholm, Sweden. Email Tran athonghi.tran@utoronto.ca. 